\title{
20: 52120490-51993924
}

National Cancer Institute

\section{Source}

National Cancer Institute. 20:52120490-51993924. NCI Thesaurus. Code C41755.

Physical location of BCAS1_Gene 